\title{
The Effect of Motivation and Compensation on Employee Performance PT. Kebab Turki Baba Rafi Surabaya Branch with Work Satisfaction as an Intervening Variable
}

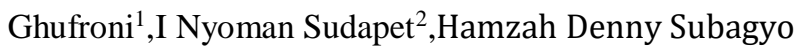 \\ Ronigufron95@gmail.com ${ }^{1}$,Nyomansudapet1@gmail.com ${ }^{2}$,Dennysalon@gmail.com \\ Departement of Management, Faculty of Economics and Business, Narotama University \\ J1. Arif Rahman Hakim 51, Surabaya, Indonesia 60117
}

\begin{abstract}
The purpose of this study is 1 . To analyze the effect of motivation on employee satisfaction at PT. Kebab Turki Baba Rafi Surabaya branch 2. To analyze the effect of motivation on employee performance at PT. Kebab Turki Baba Rafi Surabaya branch3. To analyze the effect of compensation on employee satisfaction at PT. Kebab Turki Baba Rafi Surabaya branch 4. To analyze the effect of compensation on employee performance at PT. Kebab Turki Baba Rafi Surabaya branch 5. To analyze the influence of employee satisfaction on employee performance at PT. Kaba Turki Baba Rafi branch of Surabaya. This research is quantitative research. The population and samples were distributed by 58 respondents. Data collection techniques using a questionnaire. Analysis of the data used is Convergent Validity, Discriminant Validity, Reliability and Average Variance Extracted (AVE). The results showed the effect of the Motivation variable (X1) on Employee Satisfaction (Y1) was significant at 0.002. And Motivation (X1) is not significant with Employee Performance variable (Y2) of 0.297 which means negative. based on the correlation for the Compensation variable (X2) on Employee Satisfaction (Y1) of 0.880 which means negative. And for the Compensation variable (X2) on Employee Performance (Y2) of 0.691 which means negative. And for the Employee Satisfaction variable (Y1) on Employee Performance (Y2) of 0.009 which means strong. The results of this study indicate that, Motivation has a significant effect on employee satisfaction, which leads to employee performance. And employee satisfaction has a significant effect on employee performance.
\end{abstract}

Keywords: Motivation, Compensation, Employee Satisfaction, and Employee Performance

\section{INTRODUCTION}

PT. Kebab Turki Baba Rafi is a company engaged in the culinary field. This company was founded in 2005 in Surabaya. PT. Kebab Turki Baba Rafi now has more than 1000 outlets spread across various cities in Indonesia, and the otlet in Surabaya has around 66 Surabaya branch vehicles and 15 Surabaya franchise otlets, even PT. Kebab Turki Baba Rafi has outlets outside Indonesia. At this time the competition in the culinary business is getting tighter and tighter. This requires the company to improve and develop the company by holding various activities to improve employee performance in order to gain profits.

Motivation is an encouragement given by the company so that employees have the desire to do the best of what they do. Compensation is a reward given by the company to employees for the work it produces. Giving compensation to employees must be decent and fair, because it can improve the ability of employees to improve work productivity, this is because employees can feel satisfaction in carrying out their work. Giving compensation to employees can motivate and provide job satisfaction. The employee job satisfaction factor is very important for the company because with the satisfaction of employees, it is hoped that it will further improve performance and impact on increasing the overall productivity of the company.

With the existence of good employee performance, it is expected that consumers will feel satisfied with the existing services. One way for companies to improve employee performance is to provide motivation and compensation. Because the company sets a good standard of work to improve the performance of the company in order to improve the performance of the company in facing business competition and achieving company goals. But, in terms of achieving these objectives there is also a failure, such as not achieving the goals set by the company. Therefore, to be able to achieve company goals, employees must be motivated and compensated so that in carrying out their duties more energetically and better. 
This research was conducted because the researchers saw that PT. Kebab Turki Baba Rafi, the Surabaya branch is increasingly being visited by consumers. PT. Kebab Turki Baba Rafi, the Surabaya branch has a strategic location on Nginden Semolo Road which includes an area adjacent to several college campuses. In terms of the consumer segment, students are a potential segment for culinary or food businesses because most students rarely cook their own food or food, so they must buy their food needs. In the area of business, this also includes a crowded traffic area that is crowded with motorists. This potential should be maintained by paying attention to what consumers want so that consumers get satisfaction and recommend to others. For this reason, an evaluation of what is needed by employees is needed and the effect on improving employee performance through scientific research.

Based on the description of the background above, the researchers are interested in conducting research with the title "The Effect of Motivation and Compensation on Employee Performance with Job Satisfaction As an Intervening Variable at PT. Kebab Turki Baba Rafi, Surabaya Branch ".

\section{Research purposes}

The objectives of this study include:

1. To analyze the effect of motivation on employee satisfaction at PT. Kebab Turki Baba Rafi Surabaya branch.

2. To analyze the effect of motivation on employee performance at PT. Kebab Turki Baba Rafi Surabaya branch.

3. To analyze the effect of compensation on employee satisfaction at PT. Kebab Turki Baba Rafi Surabaya branch.

4. To analyze the effect of compensation on employee performance at PT. Kebab Turki Baba Rafi Surabaya branch.

5. To analyze the influence of employee satisfaction on employee performance at PT. Kebab Turki Baba Rafi Surabaya branch.

\section{Motivation}

Luthans (2006) namely motivational motivation is a driver for achievement that comes from within a person or which is intrinsic. Motivation for hygiene or maintenance are factors that originate from outside a person or that are extrinsic. Ayub, Nadia (2011) in his research states that there is a positive relationship between work motivation and job satisfaction. The same thing was expressed by Saeed, Rashid, Rab Nawaz Lodhi, Hafiz, Muhammad Abdul Hayee \& Shakeel, Zahid Mahmood (2013) which stated that extrinsic motivation has a positive relationship with job satisfaction. While Gungor (2011) states that intrinsic motivation and extrinsic motivation have a positive impact on employee performance. In line with previous research, Musriha (2011) stated that work motivation significantly affected employee performance. Anyim, Chukwudi Francis, Odogwu Christopher Chidi \& Badejo (2012) in his research stated that employee motivation is an effective strategy to improve the performance of employees in the organization.

\section{Compensation}

Compensation is all income in the form of money or goods directly or indirectly received by employees in return for services provided to companies, Hasibuan (2009)Based on some of the above meanings, it can be said that compensation is all forms of payment / compensation given by the company to employees as a reward for the contribution that has been given to the company to realize the company's goals.

Hasibuan, Melayu (2007)states that compensation is a reflection of the organization to maintain human resources. Dwijayanti (2013) financial compensation is all income in the form of money, both directly and indirectly received by employees in return for remuneration provided by the company. Nugroho (2012)compensation can be interpreted as a substitute for performance consisting of financial compensation such as basic salary, incentives, and other benefits. Sopiah (2013) Compensation is something that is accepted by employees to be more motivated in completing work and creates satisfaction for employees.

\section{Job satisfaction}

According toHandoko (2014: 193) job satisfaction is a pleasant or unpleasant emotional state with which employees view their work. Aziri(2011)states that job satisfaction is different for different people, job satisfaction is an attitude, an internal state, for example, associated with feelings of achievement, both quantitative and qualitative. According to Aziri (2011) states job satisfaction is a statement of pleasure and positivity which is the result of an assessment of a job or work experience. According toRobbins, Stephen P., (2014) job satisfaction is a positive feeling about work that results from an evaluation of its characteristics. Rae (2013) job satisfaction is an important part of the employee's life experience at work, meaning that relating to an 
employee receiving enough intrinsic and extrinsic rewards encourages employees to stay in their workplace and continues to spend most of their time fulfilling their duties. Ardana, I Komang, Ni Wayan Mujiati (2012) Job satisfaction needs to be preceded by the affirmation that the problem of job satisfaction is not a simple matter, both in terms of the concept and in the meaning of the analysis, because satisfaction has a variety of connotations. Job satisfaction is a general attitude of employees towards their work and as a difference

\section{Employee performance}

Employee performance is one measure that is often used in determining organizational effectiveness. An organization or company will not be able to develop if the performance of its employees also does not increase, especially with the increasing level of competition in the business world. An employee's performance can continue to increase if the employee feels job satisfaction, which can be interpreted as a pleasant emotional state by which employees see their work. Job satisfaction also reflects a person's feelings for his job. Job satisfaction is the impact of the employee's positive attitude towards work and everything that is faced in his work environment.Bernardin, John H., \& Russel \& E. A (1993: 378) provide a definition of work performance as follows, "Performance is defined as a therecord of outcomes produced on an aspecified job function or activity during a specified time period". Job performance is defined as a record of the results obtained through certain Job functions or activities for a certain period of time. A person's work performance is influenced by skills, skills, experience, sincerity and the work environment itself. The measures of employee performance proposed by Bernardin, John H., \& Russel \& E. A (1993:135)cited by Faustino Cardoso Gomes in his book HumanResource Management are as follows: 1. Quantity of work, the amount of work carried out within a specified period. 2. Quality of work, the quality of work achieved based on the conditions of suitability and preparedness. 3. Job Knowledge, the breadth of knowledge about work and skills. 4. Creativeness, authenticity of ideas raised and actions to solve problems that arise. 5. Cooperation, willingness to cooperate with other people or fellow members of the organization 6. Dependability, awareness to be trustworthy in terms of attendance and completion of work. 7. Initiative, enthusiasm for carrying out new tasks and enlarging its responsibilities. 8. Personal Qualities, concerning personality, leadership, hospitality and personal integrity.

\section{Previous research}

1. Kadek, Juniari, \& Riana, (2015) The purpose of this study was to analyze the effect of motivation on job satisfaction, employee performance, and to analyze the effect of job satisfaction on employee performance. The population of this study was all civil servants at the Nusa Dua Tourism School in Bali with a total sample of 74 respondents who were selected using simple random sampling techniques. Data was collected through questionnaires distributed to respondents then analyzed using descriptive analysis and LeastSquare (PLS) Partial. The results showed that a) motivation has a positive and significant effect on job satisfaction, b) motivation has a positive and significant effect on employee performance, c) job satisfaction has a positive and significant effect on employee performance. The implication of this study is that with the award and recognition of work results and supported by a fair system of supervision will be able to increase motivation and stimulate employee morale to complete their work, so that it will be able to improve employee performance both in terms of quality and quantity.

2. Luh, Sri, \& Sudibia (2015)This study aims to analyze the effect of job insecurity and financial compensation on job satisfaction and turnover of contract employee intention at Bali Dynasty Resort. This study used 79 respondents by taking respondents from permanent employees and contract employees. Testing is done by path analysis techniques (Path Analysis), Based on the results of the analysis concluded job insecurity variables have a positive and significant effect on job satisfaction, job insecurity variables have a negative and significant effect on job satisfaction, financial compensation has a positive effect on job satisfaction, compensation variables financial has a negative and significant influence on turnover intention, the variable job satisfaction has a negative and significant effect on turnover intention. The implication of this research is that to avoid the desire of employees to find new jobs in other companies it can be done by applying career paths for these employees so that contract employees feel that their work has more benefits in the future.

3. Gachengo \& Wekesa (2017)The purpose of this study was to determine the effect of motivation on the performance of National Bank of Kenya employees. In connection with this, the key factors that influence motivation are especially training, the reward system; performance appraisal and work life balance are analyzed. The findings of the study will help human resource managers, NBK employees, academics, policy makers and other relevant decision makers to develop mechanisms for dealing with employee motivation to improve performance and impact. This study adopted a descriptive design. The target population consists of management officials and subordinate officials totaling 124. Stratified random sampling was adopted to select a sample size of 95 respondents. The questionnaire was used as the main 
data collection instrument that was personally managed by the researcher. Data analysis was performed using descriptive and inferential statistics assisted by SPSS Version 21. Descriptive statistics, the average involved, standard deviation, frequency distribution and percentage while for inferential statistics involved bivariate correlation and multi regression analysis. This study found that motivation had a statistically significant effect on employee performance at National Bank of Kenya.

\title{
Hypothesis
}

The hypothesis formulated is:

H1: motivation has a positive and significant effect on employee performance.

$\mathrm{H} 2$ : motivation has a positive and significant effect on job satisfaction.

H3: Compensation has a positive and significant effect on employee performance.

H4: Compensation has a positive and significant effect on job satisfaction

H5: Job satisfaction has a positive and significant effect on employee performance.

\section{RESEARCH METHODOLOGY}

\section{Types of research}

This study uses an associative quantitative approach. Quantitative approach is a research method that is used to examine a population or a particular sample that aims to test a predetermined hypothesis (Nurcahyani \& Adnyani, 2016). This study is in the form of associative, namely research that aims to determine the relationship between two or more variables(Nurcahyani \& Adnyani, 2016). The object of this research was conducted by researchers at PT. Kebab Turki Baba Rafi, Surabaya Branch. The independent variables in this study are motivation and compensation, job satisfaction as intervening variables and employee performance as the dependent variable.

\section{Population and Samples}

In the population research is the entire employee of PT. Kebab Turki Baba Rafi, Surabaya Branch which numbered 58 employees. For the sake of obtaining samples of representative samples using a method method. This is done because the number of populations is relatively small, so that the researchers are trying to take the entire population to be made as samples until the number of samples is obtained by a total of 58 samples.

\section{Analysis Method}

\author{
Data analysis technique \\ In this study researchers used PLS data analysis techniques.
}

\section{Structural Model (Inner Model)}

Ghozali (2015) inner model which is sometimes referred to as (inner relations, structural model, and substantive theory) illustrates the relationship between latent variables based on the substantive theory.

\section{Measurement Model (Outer Model)}

\section{Weight Relations}

Ghozali (2015)Outer model shows that each indicator block is related to its latent variables.

Ghozali (2015) Outer and Inner models provide specifications followed in PLS algorithm estimation.

\section{Evaluation of Structural Models (Inner Model)}

Ghozali, 2015)inner model which is sometimes referred to as (inner relations, structural model, and substantive theory) illustrates the relationship between latent variables based on subtantive theory. Structural models are evacuated with PLS. By using R-Square for endogenous (dependent) latent variables. The interpretation is the same as the interpretation in OLS regression. Changes in the R-Squares value can be used to assess the effect of exogenous latent variables (independent) on endogenous variables (dependent) whether they have substantive effects.

\section{Evaluation of Reflexive Indicator Measurement Model (Outer Model)}

According to Ghozali and Aprilia (2016: 37-38) Convergent validity of the measurement model with a reflective indicator is assessed based on the value of loading factors of each indicator forming a latent construct. A construct is said to have good convergent validity if the loading factor is more than 0.70 and is significant. But for researchers in the early stages of developing a measurement scale, the loading values of 0.5 to 0.6 are considered sufficient. Discriminant validity measurement models with reflective indicators are assessed by comparing the square root value of average variance extracted (AVE) of each latent construct with the correlation between constructs related to other constructs in the model. If the AVE square root value of each 
construct is greater than the correlation value between constructs and other constructs in the model, then it has good discriminant validity.

\section{Quality Indexes}

PLS path modeling can also identify global optimization criteria to find out the goodness of fit of the same model as CB-SEM. For PLS path modeling provides three different fit indexes, namely communaly index, redundancy index, and goodness of fit $(\mathrm{GoF})$ index.

\section{RESULTS AND DISCUSSION}

\section{Convergent Validity}

Table 4.5

Outer Loadings (Measurement Model)

\begin{tabular}{|l|l|l|l|l|}
\hline & X1 & X2 & Y1 & Y2 \\
\hline X1.1 & 0.548 & & & \\
X1.2 & 0.881 & & & \\
X2.1 & 0.864 & & & \\
X2.2 & & 0.869 & & \\
X2.3 & & 0.564 & & \\
X2.4 & & 0.944 & & \\
Y1.1 & & 0.941 & & \\
Y1.2 & & & 0.898 & \\
Y1.3 & & & 0.912 & \\
Y2.1 & & & 0.591 & \\
Y2.2 & & & & 0.965 \\
Y2.3 & & & & 0.962 \\
Y2.4 & & & & 0.964 \\
\hline
\end{tabular}

The results of processing using SmartPLS can be seen in Table 4.5. The value of the outer model or the correlation between the construct and the latent variable has met convergence validity because the value of the loading factor in the table above is not below the limit of the loading factor of 0.50 .

\section{Discriminant Validity}

Discriminant validity is done to ensure that each concept of each latent variable is different from the other variables. The model has good discriminant validity if each loading value from each indicator of a latent variable has the highest loading value with other loading values for other latent variables. The results of discriminant validity testing are obtained as follows:

Table 4.6

Value Discriminant Validity

(Cross Loading)

\begin{tabular}{|c|c|c|c|c|}
\hline & $\mathbf{X 1}$ & $\mathbf{X 2}$ & Y1 & Y2 \\
\hline $\mathbf{X 1 . 1}$ & $\mathbf{0 . 5 4 8}$ & 0.208 & 0.061 & 0.043 \\
$\mathbf{X 1 . 2}$ & $\mathbf{0 . 8 8 1}$ & 0.263 & 0.359 & 0.038 \\
$\mathbf{X 1 . 3}$ & $\mathbf{0 . 8 6 4}$ & 0.070 & 0.291 & 0.066 \\
$\mathbf{X 2 . 1}$ & 0.238 & $\mathbf{0 . 8 6 9}$ & 0.054 & 0.014 \\
$\mathbf{X 2 . 2}$ & 0.120 & $\mathbf{0 . 5 6 4}$ & 0.008 & 0.038 \\
$\mathbf{X 2 . 3}$ & 0.154 & $\mathbf{0 . 9 4 4}$ & 0.035 & 0.088 \\
$\mathbf{X 2 . 4}$ & 0.229 & $\mathbf{0 . 9 4 1}$ & 0.046 & 0.056 \\
Y1.1 & 0.256 & 0.052 & $\mathbf{0 . 8 9 8}$ & 0.268 \\
Y1.2 & 0.307 & 0.036 & $\mathbf{0 . 9 1 2}$ & 0.233 \\
Y1.3 & 0.300 & 0.216 & $\mathbf{0 . 5 9 1}$ & 0.248
\end{tabular}




\begin{tabular}{|l|l|l|l|l|} 
Y2.1 & 0.034 & 0.006 & 0.289 & $\mathbf{0 . 9 6 5}$ \\
Y2.2 & 0.076 & 0.088 & 0.268 & $\mathbf{0 . 9 6 2}$ \\
Y2.3 & 0.057 & 0.069 & 0.313 & $\mathbf{0 . 9 6 4}$ \\
Y2.4 & 0.060 & 0.150 & 0.323 & $\mathbf{0 . 9 5 3}$ \\
\hline
\end{tabular}

Table 4.6 can be seen that the value of the loading factor for each indicator of each latent variable has the highest loading factor value if it is associated with other latent variables. This means that every latent variable has good discriminant validity.

\section{Evaluating Reliability and Average Variance Extracted (AVE)}

Validity and reliability criteria can also be seen from the reliability value of a construct and the value of Average Variance Extracted (AVE) of each construct. Constructions are said to have high reliability if the value is 0.70 and AVE is above 0.50. In table 4.9, the Composite Reliability and AVE values will be presented for all variables.

\section{Tabel 4.7}

Composite Reliability dan Average Variance Extracted

\begin{tabular}{|c|c|c|}
\hline & Composite Reliability & AVE \\
\hline X1 & 0.817 & 0.608 \\
X2 & 0.905 & 0.713 \\
Y1 & 0.851 & 0.663 \\
Y2 & 0.980 & 0.924 \\
\hline
\end{tabular}

Based on table 4.7. it can be concluded that all constructs meet reliable criteria. This is indicated by the composite reliability value above 0.70 and AVE above 0.50 as the recommended criteria.

\subsubsection{Testing of Structural Models (Inner Model)}

Testing the inner model or structural model is done to see the relationship between constructs, significance values and R-square of the research model. The structural model is evaluated using R-square for the dependent construct of the $t$ test and the significance of the structural path parameter coefficients.

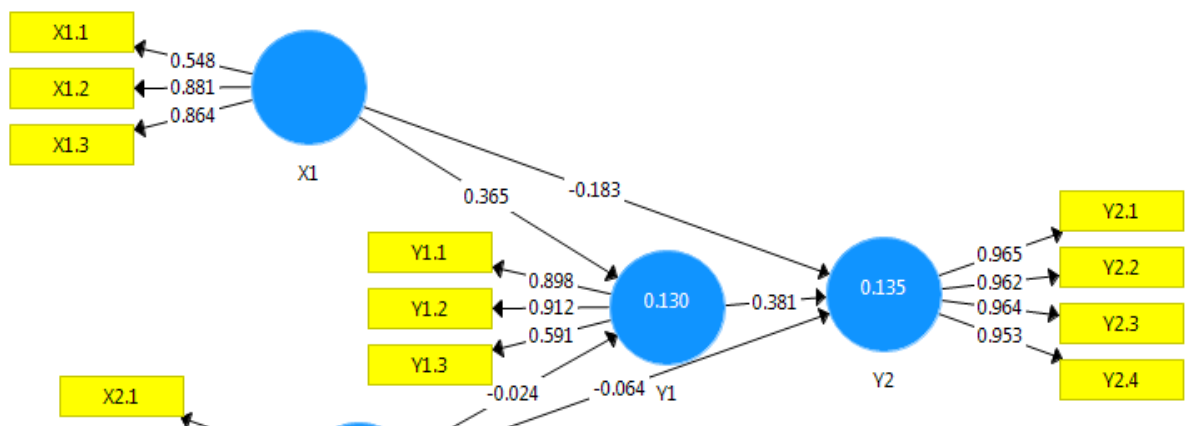


In assessing the model with PLS it starts by looking at the R-square adjusted for each dependent latent variable.

Tabel 4.8

R Square Adjusted

\begin{tabular}{|l|l|}
\hline \multicolumn{2}{|c|}{ R Square Adjusted } \\
\hline \multicolumn{1}{|c|}{ Variabel } & R Square Adjusted \\
\hline Job Satisfaction (Y1) & $0,098(9,8 \%)$ \\
Employee Performance (Y2) & $0,087(8,7 \%)$ \\
\hline
\end{tabular}

In this study consisted of 3 variables, namely the independent variable (free) as much as 1 variable namely Motivation (X1), intervening variables as much as 1 variable namely Employee Satisfaction (Y1), and the dependent variable as much as 1 namely Employee Performance (Y2). Table 4.8 shows the value of R Square Adjusted for the Employee Satisfaction variable (Y1) obtained at 0.098 for the Employee Performance variable (Y2) obtained at 0.087 . These results indicate that $9.8 \%$ of Employee Satisfaction (Y1) variables can be influenced by Motivation (X1), while Employee Performance (Y2) can be influenced by Motivation variables (X1), and Employee Satisfaction (Y1) with a value of $9.8 \%$.

\section{Hypothesis testing}

The significance of the estimated parameters provides very useful information about the relationship between the research variables. The basis used in testing hypotheses is the value found in the output Path coefficent. The table provides estimated output for testing structural models.

Tabel 4.9

Value ofPath Coefficient

\begin{tabular}{|c|c|c|c|c|c|}
\hline & $\begin{array}{c}\text { Original } \\
\text { Sample }(0)\end{array}$ & $\begin{array}{c}\text { Sample } \\
\text { Mean (M) }\end{array}$ & $\begin{array}{l}\text { Standard } \\
\text { Deviation } \\
\text { (STDEV) }\end{array}$ & $\begin{array}{c}\text { T Statistics } \\
\text { (|O/STERR|) }\end{array}$ & P-Value \\
\hline $\begin{array}{l}(\mathbf{X 1})->(\text { Y1 }) \\
(\mathbf{X 1})->(\mathbf{Y} 2) \\
(\mathbf{X 2})->(\mathbf{Y 1}) \\
(\mathbf{X 2})->(\mathbf{Y 2}) \\
(\mathbf{Y 1})->(\mathbf{Y 2})\end{array}$ & $\begin{array}{l}0.365 \\
0.183 \\
0.024 \\
0.064 \\
0.381\end{array}$ & $\begin{array}{l}0.390 \\
0.190 \\
0.043 \\
0.018 \\
0.370\end{array}$ & $\begin{array}{l}0.117 \\
0.144 \\
0.161 \\
0.161 \\
0.145\end{array}$ & $\begin{array}{l}3.108 \\
1.264 \\
0.151 \\
0.397 \\
2.624\end{array}$ & $\begin{array}{l}0,002 \\
0,297 \\
0,880 \\
0,691 \\
0,009\end{array}$ \\
\hline
\end{tabular}

Source: processing data with PLS

Hypothesis testing will be done by means of boostrapping to see $t$ statistics and p-values with a significant level of 5\% (1960). So that the acceptance criteria or rejection of the hypothesis is HA accepted and H0 rejected when the t-statistic shows> 1960, and to reject or accept the hypothesis using probability values, then Ha will be accepted if $\mathrm{p}$-value $<0.05$. The test results with bootstrapping from PLS analysis are as follows:

\section{Discussion}

\section{Effect of Motivation (X1) on Employee Job Satisfaction (Y1)}

Based on the results of the analysis using smartPLS, it can be concluded that the construct of Motivation has a significant effect on the construct of Employee Satisfaction. This can be seen from the t value of 3.108. This value is greater than table $(1,960)$. Thus, the H1 hypothesis in this study was accepted. This shows that good motivation will cause employees to be satisfied with Kebab Turki Baba Rafi.

This is contrary to the research conducted Kadek et al. (2015) which shows that motivation does not have a significant effect on employee satisfaction. 


\section{Effect of Motivation (X1) on Employee Performance (Y2)}

Based on the results of the analysis using smart PLS, it can be concluded that the Motivation construct has no significant effect on the Employee Performance construct. This can be seen from the $t$ value of 1,264. This value is smaller than $\mathrm{t}$ table $(1,960)$. Thus, the $\mathrm{H} 2$ hypothesis in this study was not accepted. This shows that good motivation will encourage employees to work to perform at PT. Kebab Turki Baba Rafi.

This is also supported by research conducted by (Purnomo, 2016). It is known that simultaneously Motivation has a significant effect on Employee Performance. ., Kadek et al., (2015)) showed that Motivation had a significantly negative effect on Employee Performance.

\section{Effect of Compensation (X2) on Employee Job Satisfaction (Y1)}

Based on the results of the analysis using smart PLS, it can be concluded that the Compensation construct has no significant effect on the construct of Employee Satisfaction. This can be seen from the $t$ value of 0.151 . This value is smaller than $\mathrm{t}$ table $(1,960)$. Thus, the $\mathrm{H} 3$ hypothesis in this study was not accepted. This shows that good compensation will cause employees to be satisfied with PT. Kebab Turki Baba Rafi.

This is also supported by the research conducted by (Sadzwina \& Gilang, 2015)S. It is known that Compensation has an effect on satisfaction with sufficient significance. Omuya (2018)shows that Compensation has a simultaneous effect on employee satisfaction of $56.4 \%$.

\section{Effect of Compensation (X2) on Employee Performance (Y2)}

Based on the results of the analysis using smart PLS, it can be concluded that the compensation construct has no significant effect on the construct of employee performance. This can be seen from $t$ at 0.397 . This value is smaller than $\mathrm{t}$ table $(1,960)$. Thus, the H4 hypothesis in this study was not accepted. This shows that good compensation will encourage employees to work to perform employee performance at PT. Kebab Turki Baba Rafi.

This is also supported by research conducted by Luh et al., (2015) that compensation has an influence on employee performance by $50.2 \%$, the remaining $49.8 \%$ is influenced by other factors. While partially shows that tangible variables (physical evidence), reliability (reliability), assurance (guarantee) and empathy (empathy) have a significant effect on employee performance. Suwandana, (2016) shows that the results of the research partially obtained variable compensation and motivation have a negative and not significant effect on employee performance.

\section{Effect of Employee Satisfaction (Y1) on Employee Performance (Y2)}

Based on the results of the analysis using smart PLS, it can be concluded that the construct of employee satisfaction has a significant effect on the construct of employee performance. This can be seen from t of 2,624. This value is greater than $t$ table $(1,960)$. Thus, the H5 hypothesis in this study was accepted. This shows that satisfied employees are very influential to work to perform employee performance at PT. Kebab Turki Baba Rafi. This is also supported by research conducted Purnomo, (2016) it is known that a very positive relationship between employee satisfaction and employee performance.

\section{CONCLUSIONS AND RECOMMENDATIONS Conclusion}

Based on the problems that have been formulated, the results of analysis and testing of hypotheses that have been carried out beforehand, since the research carried out can be taken as a conclusion as follows:

1. The results of data processing indicate a significant influence between Motivational variables on Employee Satisfaction with a p-value of 0.002 and a $t$ value of 3.108. Based on the results of data processing, this means that good motivation will cause employees to be satisfied with PT. Kebab Turki Baba Rafi.

2. The results of data processing show no significant effect between Motivation variables on Employee Performance Interest with a p-value of 0.297 and a t value of 1.264. Based on the results of data processing, this means that good motivation will encourage employees to perform employee performance at PT. Kebab Turki Baba Rafi.

3. The results of data processing show that there is no significant effect between compensation variables on Employee Satisfaction with a p-value of 0.880 and a t value of 0.151. Based on the results of data processing, this means that good compensation will cause employees to be satisfied with PT. Kebab Turki Baba Rafi. 
4. The results of data processing show that there is no significant effect between the Compensation variable on Employee Performance with a p-value of 0.691 and a t value of 0.397. Based on the results of data processing, this means that good compensation will encourage employees to perform employee performance at PT. Kebab Turki Baba Rafi.

5. The results of data processing indicate a significant influence between the variable Employee Satisfaction on Employee Performance with a p-value of 0.009 and a t value of 2.624. Based on the results of data processing this means that satisfied employees are encouraged to perform at PT. Kebab

\section{Suggestion}

Based on the conclusions above, a number of suggestions are expected to be useful for owners of culinary businesses in general and owners of PT. Kebab Turki Baba Rafi in particular. The suggestions given include:

1. Motivation is a matter given by the company so that its employees have the desire to do their best from what they do because good motivation will encourage employees to be enthusiastic and employees feel at home for a long time to enjoy the atmosphere provided by the company owner, which will make employees feel satisfied. in general if employees feel satisfied will encourage them to be more excited again and tell others about the good things that have been felt. in research testing motivation is observed when it can be said to be satisfying. Because it has been seen as being significant in the Path test coefficient, so it is owned by PT. Kebab Turki Baba Rafis did not provide a slight increase in motivation because in some employees there were those who were less motivated because of the effects of the career path on employees who had worked for years at PT. Kebab Turki Baba Rafi.

2. Compensation is no less important to be considered by business people, especially in the culinary field because good compensation will make employees feel safe and comfortable while doing the work provided by the owner. Compensation in testing is also said to be satisfactory. Because it has been seen as being significant in the Path test coefficient, so it is for the owner of PT. Kebab Turki Baba Rafit remains encouraging responsive response from employees.

For the next researcher, it is expected to be able to develop further research with the same topic, but rather consider other variables or different ones that can provide solutions in relation to employee satisfaction and performance.

\section{REFERENCES}

Anyim, Chukwudi Francis, Odogwu Christopher Chidi, A. E., \& Badejo. (2012). Motivation and Employees' Performance in the Public and Private Sectors in Nigeria. Administration. International Journal of Business, Vol.3, No., pp.31-40.

Ardana, I Komang, Ni Wayan Mujiati, D. I. W. M. U. (2012). Manajemen Sumber Daya Manusia. Yogyakarta: Graha Ilmu.

Ayub, Nadia, S. R. (2011). The Relationship Between Work Motivation and Job Satisfaction. Pakistan Business Jurnals, pp.322-347.

Aziri, B. (2011). Job Satisfaction: A Literature Review. Journal of Management Research and Practice, 3 (4), pp: 77-86.

Bernardin, John H., \& Russel, J., \& E. A. (1993). Human resources management an experiental approach. (I. McGraw-Hill, ed.). Bungin, Burhan.Singapura.

Dwijayanti, K. D. (2013). Pengaruh Kompensasi Finansial, Komunikasi Dan Lingkungan Kerja Fisik Terhadap Kepuasan Kerja Karyawan Pada Bakung Sari Hotel Di Kuta-Badung. Jurnal Manajemen Dan Bisnis $(J M B)$, Vol. 1 .

Gachengo, V., \& Wekesa, S. (2017). Influence of motivation on employee performance: a case of national bank of Kenya. International Journal of Business Management and Social Research, 3(2), 179-185. https://doi.org/10.18801/ijbmsr.030217.20

Ghozali, I. (2015). Aplikasi Analisis Multivariate dengan Program IBM SPSS 23. Semarang : Badan Penerbit Universitas Diponegoro.

Gungor, P. (2011). The Relationship between Reward Management System and Employee Performance with the Mediating Role of Motivation: A Quantitative Study on Global Bank. Procedia Social and Behavioral Sciences. Vol. 24, pp.1510-1520.

Handoko, T. H. (2014). Manajemen Personalia dan Sumber Daya Manusia (Edisi Kedu; Cetakan Keduapuluh Satu, ed.). Yogyakarta: BPFE-Yogyakarta.

Hasibuan, Melayu, S. (2007). Manjemen Sumber Daya Manusia (Edisi Revi). Jakarta: Bumi Aksara.

Hasibuan, S. P. M. (2009). Manajemen Sumber Daya Manusia (cetakan ke). Penerbit PT Bumi Aksara, Jakarta. 
Kadek, N., Juniari, E., \& Riana, I. G. (2015). PENGARUH MOTIVASI TERHADAP KEPUASAN KERJA DAN KINERJA PEGAWAI NEGERI SIPIL ( PNS ) DI SEKOLAH TINGGI PARIWISATA NUSA DUA BALI Fakultas Ekonomi dan Bisnis Universitas Udayana ( UNUD ), Bali, Indonesia Fakultas Ekonomi dan Bisnis Universitas Udayana ( UNUD. 11, 823-840.

Luh, N., Sri, M., \& Sudibia, G. A. (2015). FINANSIALTERHADAP KEPUASAN KERJA DAN TURNOVER INTENTION : ( STUDI PADA KARYAWAN KONTRAK DI BALI DYNASTY RESORT ) Fakultas Ekonomi dan Bisnis Universitas Udayana (Unud), Bali, Indonesia Fakultas Ekonomi dan Bisnis Universitas Udayana ( Unud ), Bali, In. 4(4), 1047-1066.

Luthans, F. (2006). Perilaku Organisasi (Edisi Sepu). Yogyakarta : ANDI.

Musriha. (2011). Influences of Work Behavior, Work Environment and Motivation in Clove Cigarette Factories in Kudus, Indonesia. Academic Research International, Vol. 1, pp.303-314.

Nugroho, A. D. dan K. (2012). Analisis Pengaruh Kompensasi Dan Pengembangan Karier Terhadap Kepuasan Kerja Dengan Mediasi Motivasi Kerja. Jurnal Bisnis Dan Ekonomi (JBE), 19 (2).

Nurcahyani, N. M., \& Adnyani, I. G. A. D. (2016). Pengaruh Kompensasi dan Motivasi terhadap Kinerja Karyawan dengan Kepuasan Kerja sebagai Variabel Intervening. E-Jurnal Manajemen Unud, 5(1), 500 532.

Omuya, J. M. (2018). the Influence of Compensation and Rewards on Employee Performance in Public Universities in Kenya. VI(3), 700-736.

Purnomo, D. (2016). PENGARUH MOTIVASI DAN KOMPETENSI TERHADAP KEPUASAN KERJA DAN DAMPAKNYA PADA KINERJA KARYAWAN POLITEKNIK LP3I BANDUNG. 5(1), 1-8.

Rae, K. (2013). Perceptions Of Empowerment And Commitment Affect Job Satisfaction : A Study Of Managerial Level Effects. Accounting, Accountability \& Performance, Vol. 18(Issue. 1).

Robbins, Stephen P., dan T. A. J. (2014). Perilaku Organisasi (Edisi 16). Jakarta: Salemba Empat.

Sadzwina, R., \& Gilang, A. (2015). PENGARUH KOMPENSASI TERHADAP KINERJA KARYAWAN ( STUDI PADA HOTEL KARTIKA CHANDRA JAKARTA ). 2(1), 671-685.

Saeed, Rashid, Rab Nawaz Lodhi, Hafiz, Muhammad Abdul Hayee, M., \& Shakeel, Zahid Mahmood, M. A. (2013). The Effect of Extrinsic Motivational Instruments on Job Satisfaction: A Case of Pakistani Financial Services Companies. World Applied Sciences Journal, Vol. 26, N, 1657-1661.

Sopiah. (2013). The Effect Of Compensation Toward Job Satisfaction And Job Performance Of Outsourcing Employees Of Syariah Banks In Malang Indonesia. International Journal Of Learning And Development, 3 (2)(ISSN 2164-4063).

Suwandana, I. G. M. (2016). ISSN : 2302-8912 PENGARUH PEMBERDAYAAN KARYAWAN, KOMITMEN ORGANISASIONAL DAN KOMPENSASI FINANSIAL TERHADAP KEPUASAN KERJA KARYAWAN I

Gusti Agung Surya Dewi 1 Fakultas Ekonomi dan Bisnis Universitas Udayana ( Unud), Bali, Indonesia Persaingan dalam duni. 5(4), 1969-1997. 